\title{
KLASIFIKASI KUALITAS MUTU TELUR AYAM RAS BERDASARKAN FITUR WARNA DAN TEKSTUR
}

\author{
Miftahus Sholihin ${ }^{1}$, M. Ghofar Rohman ${ }^{2}$ \\ Teknik Informatika, Fakultas Teknik,Universitas Islam Lamongan \\ Jl. Veterran No. 53 A Lamongan \\ Telp / Faks. (0322) 324706 \\ E-mail: miftahus.sholihin@unisla.ac.id,ghofar.kit@gmail.com
}

\begin{abstract}
Egg quality is determined by the quality of the inside and outside of the egg. To find out the quality of eggs can be by looking at the outside in the form of skin condition, shape, size, and egg weight. In this study a system is designed to function to determine the quality of egg quality based on color and texture features. Broadly speaking, the system built consists of 4 main processes. This process begins with pre-processing which aims to improve image quality and also to change the image size. The next process is segmentation to get the egg object. The next process is feature extraction which aims to get the characteristics of each egg object. The last process is a classification that aims to determine the class of egg images entered by the user, the method used is $k$ nearest neighbor. The data used in this study were 147 egg images consisting of 85 eggs of data testing and 62 eggs of training data. The highest accuracy obtained from this study is $82.3 \%$ with a value of 8 .
\end{abstract}

Keywords: pre-processing, segmentation, feature extraction, classification

\section{PENDAHULUAN}

Sebagai salah satu bahan makanan yang di konsumsi oleh masyarakat telur mempunyai jumlah kandungan gizi dan protein yang berbeda-beda. Kandungan gizi telur antara lain air $73,7 \%$, protein $12,9 \%$, lemak 11,2\%, karbohidrat $0,9 \%$ (Komala, 2008).

Kualitas telur akan mengalami penurunan baik kualtas internal maupun kualitas eksternal. Sudaryani (2003) menyatakan kualitas telur terbagi ke dalam dua bagian yaitu kualitas isi telur bagian dalam yang meliputi kantong udara, putih telur, dan kuning telur, sedangkan kualitas telur bagian luar meliputi kebersihan dan kondisi kulit telur, warna kulit, bentuk, dan berat telur.

Cara sederhana yang bisa digunakan untuk mengetahui kualitas telur ayam adalah dengan melihat bagian luar telur berupa kulit telur, bentuk, ukuran, dan berat dari telur tersebut. Cara lain yang bisa digunakan adalah dengan menyinari telur dimana telur ditempatkan ditempat yang gelap, kemudian isi dari telur tersebut diterawang mengunakan sinar mataharai atau senter (Soeparno, 2011). Cara yang dilakukan membutuhkan waktu yang lama dan juga membutuhkan kejelian dalam pengamatan.

Wardani (2017) melakukan penelitian untuk mendeteksi kualitas telur yang didasarkan pada segmentasi warna. Penelitian ini menggunakan metode fuzzy color histrogram $(\mathrm{FCH})$ dan discrete cosine transform (DTC). Tingkat akurasi yang didapatkan pada penelitian ini adalah 81,25\% dengan metode DTC, sedangkan penggunaan metode FCH memberikan akurasi sebesar 71,8\%.

Penelitian lain yang dilakukan Salsabilaa (2016) yang melakukan penelitian terkait dengan deteksi kualitas kesegaran telur dengan menggunakan metode gray level co-occurrence matrix (GLCM). Akurasi yang didapatkan dari penelitian ini sebesar 82,35\% ketika menggunakan nilai ketetanggan 1 .

Penelitian lain yang dilakukan oleh Sholihin (2018) yang melakukan penelitian kualitas mutu telur yang didasarkan pada fitur warna. Penelitian ini memberikan akurasi tertinggi $80 \%$ ketika nilai ketetanggan 7.

Berdasarkan beberapa penelitian yang sudah ada, maka pada penelitian ini akan merancang sebuah sistem yang bisa untuk melakukan klasifikasi mutu telur ayam yang didasarkan pada fitur warna dan tekstur. Metode klasifikasi yang digunakan pada penelitian adalah $K$-Nearest Neighbor.

\section{METODE}

Data citra yang digunakan pada penelitian ini adalah data citra telur ayam ras yang diambil dari Fakultas Peternakan Universitas Islam Lamongan. Jumlah data citra yang digunakan dalam penelitian ini adalah 147 citra yang dibagi menjadi dua yaitu data training dan data testing.

Gambar 1 adalah gambaran umum sitem yang dibangun. Secara garis besar sistem yang dibangun terdiri dari 4 proses utama.

\section{Pre-processing}

Pre-processing bertujuan untuk meningkatkan kualitas citra telur yang digunakan. Pre-processing yang dilakukan pada penelitian ini adalah memperkecil ukuran dari citra telur. Proses ini dilakukan karena ukuran asli citra telur berukuran besar, hal ini bisa mempengaruhi proses komputasinya. Gambar 2 adalah citra asli telur, sedangkan Gambar 3 adalah citra hasil proses segmentasi. 


\section{Segmentasi}

Proses segmentasi dilakukan karena ketika melakukan pengambilan gambar citra telur masih ada objek selain citra telur. Proses ini diawali dengan merubah citra RGB menjadi citra grayscale, dari citra grayscale kemudian dilakukan segmentasi dengan cara merubah citra telur menjadi citra biner. Pada saat melakukan segmentasi ternyata masih ada objek selain telur yang ikut tersegmentasi. Untuk menghilangkan objek yang bukan telur maka dilakukan dengan cara menghitung jumlah piksel dari semua objek, setelah didapatkan nilai dari masing-masing objek, maka diambil nilai maksimum dari objek yang ada. Nilai maksimum dari objek yang ada yang dianggap sebagai citra telur.

\section{Ekstraksi Ciri}

Ekstraksi ciri bertujuan untuk mengambil ciri dari citra telur. Metode yang dipakai pada penelitian ini adalah GLCM dan ciri warna. Fitur GLCM yang digunakan adalah energi, kontras, korelasi, dan homogenitas (Putra, 2010). Nilai energi yang tinggi akan muncul pada saat citra cenderung seragam. Kontras merupakan perbedaan intensitas antar piksel. Kontras akan bernilai nol manakala citra konsisten. Korelasi mengukur ketidakmiripan suatu gambar dimana nilainya akan besar bila acak dan akan bernilai kecil jika seragam. Homogenitas menunjukan kehomogenan citra yang berderajat sejenis.

Ciri warna yang digunakan pada penelitian ini adalah moment pertama, moment kedua, dan moment ketiga. Jumlah ciri yang digunakan untuk ciri warna berjumlah 6 .

Jumlah ciri yang digunakan dalam penelitian ini adalah 13 yang terdiri dari ciri tekstur dan ciri warna.

\section{Klasifikasi}

Klasifikasi bertujuan untuk menentukan kelas dari citra yang dimasukan oleh pengguna. Pada penelitian ini metode yang digunakan adalah $K$ Nearest Neighbor (KNN). Prinsip kerja dari

algoritma KNN adalah mencari nilai jarak terdekat dari data uji dengan $k$ tetangga terdekatnya. Jarak terdekat dihitung dengan menggunakan jarak euclidean distance.

Pada penelitian ini proses klasifikasi dibagi menjadi dua proses yaitu proses training dan proses testing. Proses training bertujuan untuk melatih sistem. Jika proses training belum dilakukan maka sistem belum bisa bekerja. Sedangkan proses testing bertujuan untuk mengetahui tingkat keberhasilan atau akurasi sistem terhadap data masukan yang diberikan oleh pengguna. Gambar 4 adalah gambaran umum proses klasifikasi.

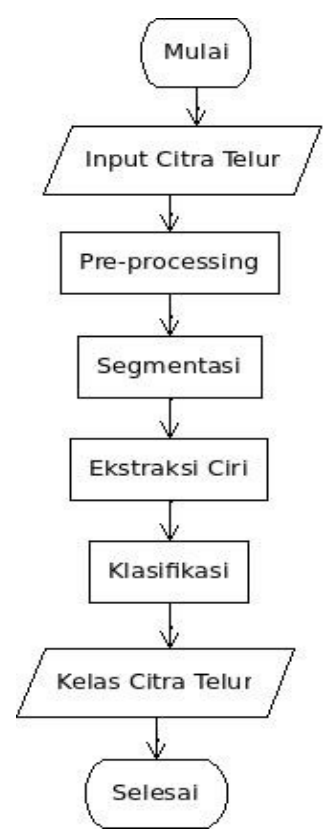

Gambar 1. Gambaran umum sistem

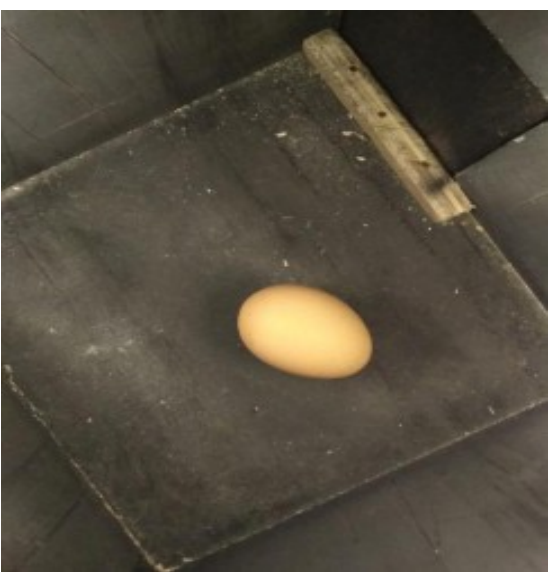

Gambar 2. Citra telur asli

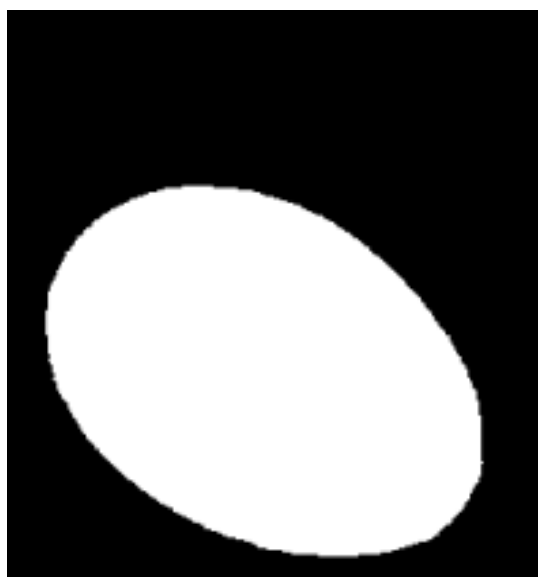

Gambar 3. Segmentasi citra telur 


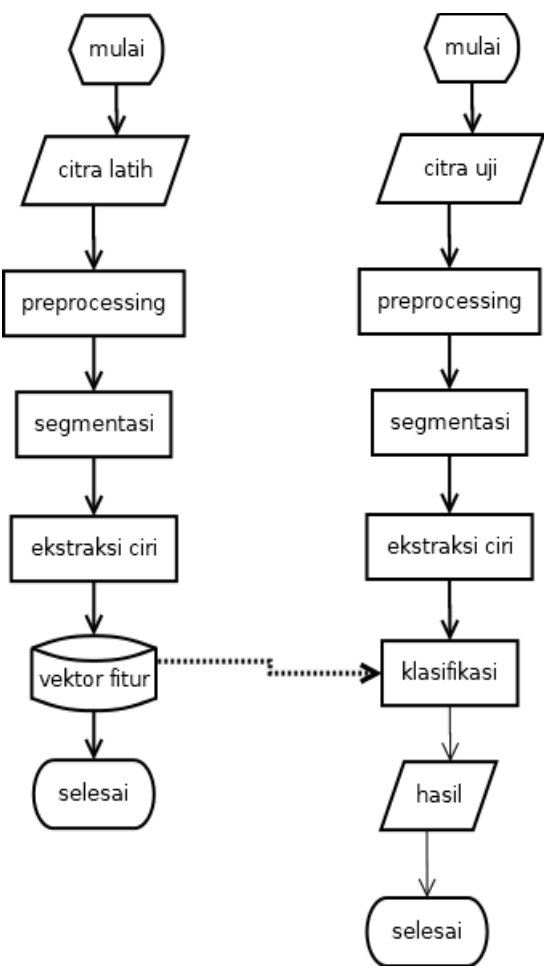

Gambar 4. Proses klasifikasi

\section{PEMBAHASAN}

Jumlah data yang digunakan dalam penelitian ini adalah 147 yang dibagi menjadi data training berjumlah 85 dan data testing berjumlah 62. Jumlah ciri yang digunakan pada penelitian ini adalah 13 . Kelas yang digunakan pada penelitian ini 3 yaitu kelas mutu I, mutu II, dan mutu III. Jumlah data citra uji dibagi menjadi mutu I 28 citra, mutu II 19 citra, dan mutu III 15 citra.

Proses pengujian bisa dikerjakan ketika sudah dilakukan proses ekstraksi ciri citra telur. Ciri yang didapatkan di simpan sebagai data training. Proses pengujian di awali dengan menentukan nilai $k$ atau ketetanggaan. Pada panelitian ini nilai $k$ atau ketetanggaan adalah 1-10. Tabel 1 adalah hasil proses klasifikasi.

Tabel 1. Hasil klasifikasi

\begin{tabular}{clccc}
\hline \multirow{2}{*}{$\begin{array}{c}\text { Nilai } \\
k\end{array}$} & Kelas & \multicolumn{3}{c}{ Hasil } \\
\cline { 3 - 5 } & & Benar & Salah & Akurasi \\
\hline 1 & Mutu I & 18 & 10 & \\
& Mutu II & 8 & 11 & $59,7 \%$ \\
& Mutu III & 11 & 4 & \\
2 & Mutu I & 21 & 7 & \\
& Mutu II & 7 & 12 & $56,5 \%$ \\
& Mutu III & 7 & 8 & \\
3 & Mutu I & 20 & 8 & \\
& Mutu II & 8 & 11 & $62,9 \%$
\end{tabular}

\begin{tabular}{|c|c|c|c|c|}
\hline & Mutu III & 11 & 4 & \\
\hline 4 & $\begin{array}{l}\text { Mutu I } \\
\text { Mutu II } \\
\text { Mutu III }\end{array}$ & $\begin{array}{c}20 \\
8 \\
11\end{array}$ & $\begin{array}{c}8 \\
11 \\
4\end{array}$ & $62,9 \%$ \\
\hline 5 & $\begin{array}{l}\text { Mutu I } \\
\text { Mutu II } \\
\text { Mutu III }\end{array}$ & $\begin{array}{c}22 \\
7 \\
9\end{array}$ & $\begin{array}{c}6 \\
12 \\
6\end{array}$ & $61,3 \%$ \\
\hline 6 & $\begin{array}{l}\text { Mutu I } \\
\text { Mutu II } \\
\text { Mutu III }\end{array}$ & $\begin{array}{c}25 \\
10 \\
7\end{array}$ & $\begin{array}{l}3 \\
9 \\
8\end{array}$ & $67,7 \%$ \\
\hline 7 & $\begin{array}{l}\text { Mutu I } \\
\text { Mutu II } \\
\text { Mutu III }\end{array}$ & $\begin{array}{c}23 \\
9 \\
8\end{array}$ & $\begin{array}{c}5 \\
10 \\
7\end{array}$ & $64,5 \%$ \\
\hline 8 & $\begin{array}{l}\text { Mutu I } \\
\text { Mutu II } \\
\text { Mutu III }\end{array}$ & $\begin{array}{l}27 \\
13 \\
11\end{array}$ & $\begin{array}{l}1 \\
6 \\
4\end{array}$ & $82,3 \%$ \\
\hline 9 & $\begin{array}{l}\text { Mutu I } \\
\text { Mutu II } \\
\text { Mutu III }\end{array}$ & $\begin{array}{c}26 \\
10 \\
7\end{array}$ & $\begin{array}{l}2 \\
9 \\
8\end{array}$ & $69,4 \%$ \\
\hline 10 & $\begin{array}{l}\text { Mutu I } \\
\text { Mutu II } \\
\text { Mutu III }\end{array}$ & $\begin{array}{c}26 \\
9 \\
7\end{array}$ & $\begin{array}{c}2 \\
10 \\
8\end{array}$ & $67,7 \%$ \\
\hline
\end{tabular}

Berdasarkan Tabel 1 akurasi tertinggi sebesar $82,3 \%$ ketika nilai $k$ atau ketetanggaan 8 . Sistem yang dibangun belum mampu mengklasifikasi telur dengan benar. Sistem yang dibangun mampu mengklasifikasikan jenis telur mutu I dengan optimal, sedangkan untuk mutu II dan III sistem masih belum mampu mengklasifikasikan dengan maksimal, hal ini disebabkan citra telur mutu II dan III terkadang memiliki intensitas warna yang mirip, sehingga sistem salah dalam melakukan klasifikasi.

\section{KESIMPULAN}

Berdasarkan uji coba yang sudah dilakukan dapat ditarik kesimpulan bahwa nilai rata-rata akurasi tertinggi untuk klasifikasi telur ayam ini sebesar $82,3 \%$ dengan nilai $k$ atau ketetanggaan 8 . Sistem yang dibangun bisa mengenali hampir seluruh citra untuk kualitas mutu I, sedangkang untuk mutu II banyak yang salah dalam klasifikasinya.

\section{PUSTAKA}

Komala, I. 2008. Kandungan Gizi Produk Peternakan. Student Master Animal Science, Fac. Agriculture-UPM.

Putra, D, 2010. Pengolahan Citra Digital, Yogyakarta: ANDI.

Salsabilaa, RK. Hidayat, M. \& Darana, S. Deteksi Kualitas dan Kesegaran Telur Ayam Ras Berdasarkan Deteksi Objek Transparan dengan Metode Grey Level Co-Occurrence Matrix dan Klasifikasi K-Nearest Neighbor. Jurnal Penelitian dan Pengembangan Telekomunikasi, 
Kendali, Komputer, Elektrik, dan Elektronika (TEKTRIKA) Juli 2016, Volume 1, Nomor 2.

Sholihin, M. \& Rohman, M.G. 2018. Klasifikasi Mutu Telur Berdasarkan Fitur Warana dengan Menggunakan Metode K-Nearest Neighbor. Seminar Nasional Sistem Informasi 2018, 9 Agustus 2018.

Soeparno. 2011. Dasar Teknologi Hasil Ternak. Gadjah Mada University Press, Yogyakarta.

Sudaryani, T. 2003. Kualitas Telur. Penerbit Swadaya Jakarta. Halaman 1, 8-10.

Wardhani, YEK. Hidayat, B. \& Darana, S. 2017. Deteksi Kualitas dan Kesegaran Telur Berdasarkan Segmentasi Warna dengan Metode Fuzzy Color Histrogram dan Discrete Cosine Transform dan Klasifikasi KNN, e-Proceeding of Engineering : Vol. 4, No. 1 April 2017. ISSN : 2355-9365 